\title{
GAMBARAN PENGETAHUAN MASYARAKAT DESA WIAU LAPI TENTANG STOMATITIS AFTOSA REKUREN
}

\author{
${ }^{1}$ Jefrianto Wololy \\ ${ }^{2}$ Billy J. Kepel \\ ${ }^{3}$ Christy N. Mintjelungan
}

\author{
${ }^{1}$ Kandidat Skripsi Program Studi Kedokteran Gigi Fakultas Kedokteran \\ Universitas Sam Ratulangi Manado \\ ${ }^{2}$ Bagian Kimia Fakultas Kedokteran Universitas Sam Ratulangi Manado \\ ${ }^{3}$ Program Studi Kedokteran Gigi Fakultas Kedokteran Universitas Sam Ratulangi Manado \\ Email: woloyjef@gmail.com
}

\begin{abstract}
Recurrent aphthous stomatitis (RAS), commonly known among Indonesian people as "sariawan", is an oral mucosal disease which most often affects people. Based on the clinical symptoms, there are three recognized types of RAS, namely: minor RAS as the most common type, major RAS, and herpetiform RAS. Knowledge about RAS is very useful in the prevention and treatment of RAS. This was a descriptive study with a cross-sectional design. Samples were 75 Wiau Lapi villagers who filled in the questionnaires and were selected by using simple random sampling. This study aimed to reveal the knowledge of the villagers of Wiau Lapi about recurrent aphthous stomatitis. The results showed that the knowledge of the villagers of Wiau Lapi about RAS tested with the questionnaire consisting of 11 questions obtained a percentage of $63.8 \%$. Conclusion: Most villagers of Wiau Lapi had good knowledge about recurrent aphthous stomatitis.
\end{abstract}

Keywords: knowledge, recurrent aphtous stomatitis.

\begin{abstract}
Abstrak: Stomatitis aftosa rekuren (SAR) atau yang umum dikenal masyarakat Indonesia sebagai "sariawan", merupakan penyakit mukosa oral yang paling sering diderita manusia. Sampai saat ini terdapat tiga jenis SAR yang dikenal, dengan gejala klinis masing-masing, yaitu: SAR minor sebagai jenis yang paling umum, SAR mayor, dan SAR herpetiformis. Pemahaman yang baik tentang SAR akan sangat bermanfaat ketika penderita berusaha menangani SAR. Penelitian ini bertujuan untuk mengetahui gambaran pengetahuan masyarakat Desa Wiau Lapi tentang stomatitis aftosa rekuren. Penelitian ini menggunakan metode deskriptif dengan cross-sectional design yang dilakukan selama satu bulan. Sampel ialah 75 penduduk desa Wiau Lapi yang mengisi kuesioner dan diseleksi dengan menggunakan simple random sampling. Hasil penelitian menunjukkan bahwa pengetahuan masyarakat Desa Wiau Lapi tentang SAR yang diuji dengan kuesioner yang meliputi 11 pertanyaan mencapai persentase sebesar $63,8 \%$. Simpulan: Pengetahuan masyarakat Desa Wiau Lapi mengenai SAR sudah tergolong baik.
\end{abstract}

Kata kunci: pengetahuan, stomatitis aftosa rekuren.

Stomatitis aftosa rekuren (SAR) atau yang umumnya dikenal masyarakat Indonesia sebagai "sariawan", merupakan penyakit mukosa oral yang paling sering diderita manusia. ${ }^{1}$ Terdapat tiga jenis SAR yang dikenal hingga saat ini dengan gejala klinis masing-masing, yaitu: SAR minor sebagai jenis yang paling umum (prevalensi 8095\% dari keseluruhan kasus SAR), SAR mayor (10-15\%), dan SAR herpetiformis (5-10\%). Umumnya SAR diderita 20-25\% dari populasi umum, dengan angka 
rekurensi dalam 3 bulan sekitar $50 \% .^{1-7}$ Beberapa negara telah melaporkan angka kejadian SAR, seperti Amerika Serikat $(60 \%)$, Swedia (2\%), Spanyol (1,9\%), dan Malaysia $(0,5 \%)$, sedangkan di Indonesia belum ada data yang pasti mengenai angka kejadian SAR. ${ }^{2}$

Desa Wiau Lapi merupakan salah satu desa yang terdapat di Kecamatan Tareran, Kabupaten Minahasa Selatan, dengan jumlah penduduk 890 jiwa. Berdasarkan survei awal, diketahui bahwa sebagian besar masyarakat Desa Wiau Lapi pernah menderita SAR. SAR merupakan masalah kesehatan mulut paling umum, tetapi sebagian besar masyarakat tidak menganggapnya sebagai masalah serius. Walaupun SAR bukan penyakit yang secara langsung berbahaya, diharapkan masyarakat telah memilliki pengetahuan yang benar mengenai SAR baik pencegahan maupun penanganan secara sederhana. ${ }^{8}$

\section{METODE PENELITIAN}

Penelitian ini menggunakan metode deskriptif dengan cross sectional design. Jumlah sampel yang diteliti berjumlah 75 orang berdasarkan perhitungan Slovin dan sampel diambil dengan teknik simple random sampling.

Pengumpulan data diperoleh melalui studi lapangan. Responden ditanyakan apakah bersedia terlibat dalam penelitian. Langkah selanjutnya ialah beberapa pertanyaan pendahuluan untuk memastikan apakah responden pernah menderita SAR atau tidak. Jika pernah, dipastikan lagi apakah penyakit yang pernah dideritanya benar merupakan SAR atau bukan. Setelah itu responden diminta mengisi kuesioner dengan didampingi oleh peneliti. Kuesioner terdiri dari 11 pertanyaan, untuk setiap jawaban benar bernilai 1 dan jawaban salah bernilai 0 . Hasil yang diperoleh kemudian dikategorikan kedalam 5 kelompok berdasarkan persentase (Tabel 1).
Tabel 1. Kategori tingkat pengetahuan responden berdasarkan hasil pengisian kuesioner.

\begin{tabular}{cc}
\hline $\begin{array}{c}\text { Hasil pengisian } \\
\text { kuesioner }(\boldsymbol{\%})\end{array}$ & Kategori \\
\hline 20 & Sangat kurang \\
40 & Kurang \\
60 & Cukup \\
80 & Baik \\
100 & Sangat baik \\
\hline
\end{tabular}

\section{HASIL PENELITIAN}

Penelitian ini dilakukan di Desa Wiau Lapi selama bulan September 2012 dengan jumlah responden 75 orang. Semua responden menyatakan pernah menderita SAR dengan gambaran klinis yang disebutkan sesuai dengan gambaran klinis SAR. Hasil penelitian ini diperoleh dari jawaban responden terhadap 11 pertanyaan yang diajukan dalam kuesioner (Tabel 2).

Berdasarkan pernah atau tidaknya mendengar informasi tentang SAR, terdapat 64 responden $(85,3 \%)$ menjawab pernah dan 11 responden $(14,7 \%)$ menjawab tidak pernah. Dari data tersebut juga diketahui bahwa informasi mengenai SAR pada 64 responden diperoleh dari masyarakat sekitar $(54,7 \%)$, media $(17,3 \%)$, dan dokter atau dokter gigi $(13,3 \%)$.

Secara umum, total skor yang dicapai oleh 75 responden ialah 526. Skor tertinggi yang mampu dicapai jika semua responden menjawab benar ialah 825. Pengetahuan responden secara umum dapat dihitung sebagai berikut: $526 / 825 \times 100 \%=63,8 \%$.

Jawaban responden terhadap pertanyaan ke-2 menunjukkan bahwa masyarakat sudah memiliki pengetahuan yang baik tentang wanita sebagai kelompok populasi yang dominan mengalami SAR. Hal ini mungkin disebabkan oleh faktor stres dan menstruasi cenderung lebih dominan pada wanita penderita SAR. ${ }^{1,2,11}$ 
Tabel 2. Sebelas pertanyaan mengenai SAR yang diajukan dalam kuesioner.

\begin{tabular}{|c|c|c|c|}
\hline \multirow[b]{2}{*}{ No } & \multirow{2}{*}{ Isi pertanyaan mengenai SAR } & \multicolumn{2}{|c|}{ Jawaban } \\
\hline & & Benar & Salah \\
\hline 1 & $\begin{array}{l}\text { berbentuk bulat, berwarna putih kekuningan dengan tepi berwarna } \\
\text { kemerahan }\end{array}$ & $74(98,7 \%)$ & $1(1,3 \%)$ \\
\hline 2 & $\begin{array}{l}\text { wanita sebagai kelompok yang lebih rentan mengalami SAR } \\
\text { dibandingkan pria }\end{array}$ & $54(72 \%)$ & $21(28 \%)$ \\
\hline 3 & penularan SAR secara genetik dari oarngtua kepada anaknya & $9(12 \%)$ & $66(88 \%)$ \\
\hline 4 & $\begin{array}{l}\text { kuman sebagai penyebab SAR akibat kebersihan mulut yang tidak } \\
\text { dijaga }\end{array}$ & $65(86,7 \%)$ & $10(13,3 \%)$ \\
\hline 5 & daya tahan tubuh yang menurun sebagai penyebab SAR & $62(82,7 \%)$ & $13(17,3 \%)$ \\
\hline 6 & alergi sebagai penyebab SAR & $23(30,7 \%)$ & $52(69,3 \%)$ \\
\hline 7 & $\begin{array}{l}\text { cedera mukosa akibat tergigit atau tertusuk sesuatu sebagai } \\
\text { penyebab SAR }\end{array}$ & $62(82,7 \%)$ & $13(17,3 \%)$ \\
\hline 8 & stress atau menstruasi sebagai penyebab SAR & $18(24 \%)$ & $57(76 \%)$ \\
\hline 9 & B12 sebagai pengobatan yang tepat bagi SAR & $60(80 \%)$ & $15(20 \%)$ \\
\hline 10 & $\begin{array}{l}\text { makanan yang berasa asam, asin, atau pedas yang harus dihindari } \\
\text { ketika menderita SAR }\end{array}$ & $38(50,7 \%)$ & $37(49,3 \%)$ \\
\hline 11 & $\begin{array}{l}\text { menyikat gigi (minimal } 2 \text { kali sehari) sebagai pencegahan yang } \\
\text { efektif terhadap SAR }\end{array}$ & $61(81,3 \%)$ & $14(18,7 \%)$ \\
\hline
\end{tabular}

Jawaban responden terhadap pertanyaan ke-3 menunjukkan bahwa masyarakat masih sangat kurang mengetahui bahwa SAR dapat diwariskan secara genetik. Sekitar $40-50 \%$ pasien SAR memiliki riwayat SAR dalam keluarganya. ${ }^{1,2,12}$

Jawaban responden terhadap pertanyaan ke-4 menunjukkan bahwa masyarakat sudah sangat baik mengetahui bahwa bakteri turut terlibat dalam kejadian SAR. Beberapa bakteri seperti Prevotella, Heliobacter pylori, dan Streptococcus sanguis seringkali dilaporkan terlibat pada beberapa penelitian tentang SAR. ${ }^{2,11,13}$

Jawaban responden terhadap pertanyaan ke-5 menunjukkan bahwa masyarakat sudah sangat baik mengetahui bahwa daya tahan tubuh yang menurun merupakan salah satu penyebab SAR. Beberapa penelitian sebelumnya telah melaporkan tentang keterlibatan sistem imun yang melemah sebagai penyebab SAR walaupun antigen yang terlibat belum diketahui secara pasti. ${ }^{1,14,15}$

Jawaban responden terhadap pertanyaan ke-6 menunjukkan bahwa masyarakat masih kurang mengetahui bahwa alergi merupakan salah satu penyebab SAR. Beberapa penelitian sebelumnya telah melaporkan tentang reaksi hipersensitif yang terjadi akibat mengonsumsi atau kontak terhadap beberapa bahan makanan dan minuman, sodium lauryl sulfate (SLS) pada pasta gigi, maupun bahan kimia lain. $1,8,9,11,12$

Jawaban responden terhadap pertanyaan ke-7 menunjukkan bahwa masyarakat sudah sangat baik mengetahui bahwa trauma dapat menyebabkan SAR. Trauma yang dimaksud khususnya akibat menyikat gigi, gigitan pada mukosa pipi atau bibir, atau pada daerah injeksi anastesi lokal dapat menjadi faktor penyebab SAR, walaupun hubungan trauma dengan SAR belum dapat diketahui secara jelas. ${ }^{1,5,16}$

Jawaban responden terhadap pertanyaan ke-8 menunjukkan bahwa masyarakat masih sangat kurang mengetahui bahwa stres atau menstruasi merupakan penyebab SAR. Stres atau menstruasi (dalam hal ini perubahan hormonal yang terjadi) seringkali disebutkan sebagai penyebab SAR terutama pada kelompok wanita walaupun belum dapat dijelaskan secara pasti. ${ }^{1,5,11,12,16}$

Jawaban responden terhadap pertanyaan ke-9 menunjukkan bahwa masyarakat sudah sangat baik mengetahui bahwa vitamin B12 merupakan salah satu pengobatan SAR. Beberapa penelitian sebelumnya telah melaporkan tentang hasil yang 
sangat memuaskan dengan terapi vitamin B12 pada kasus SAR.,

Jawaban responden terhadap pertanyaan ke-10 menunjukkan bahwa masyarakat sudah cukup mengetahui bahwa ketika mengalami SAR penderita harus menghindari makanan yang berasa asam, asin, atau pedas. Altenburg dan Zouboulis ${ }^{17}$ mengemukakan bahwa jenis makanan yang harus dihindari antara lain makanan yang keras, asam, asin, dan pedas karena dapat memicu munculnya ulkus baru dan memperpanjang usia ulkus yang ada. Sebagai contoh jenisjenis makanan tersebut ialah kacang, coklat, jeruk nipis, minuman beralkohol dan berkarbonasi.

Jawaban responden terhadap pertanyaan ke-11 menunjukkan bahwa masyarakat sudah sangat baik mengetahui bahwa menyikat gigi secara teratur merupakan salah satu upaya pencegahan SAR. Sebuah penelitian sebelumnya telah melaporkan hasil yang memuaskan dalam usaha pencegahan SAR yaitu dengan menyikat gigi secara teratur. ${ }^{15}$

\section{SIMPULAN}

Dari hasil penelitian pada masyarakat Desa Wiau Lapi dapat disimpulkan bahwa pengetahuan masyarakat tentang SAR sudah tergolong baik.

\section{SARAN}

Disarankan kepada Dinas Kesehatan khususnya di daerah Minahasa Selatan untuk lebih meningkatkan kegiatan yang mencakup sosialisasi kepada masyarakat tentang pentingnya kesehatan gigi dan mulut serta penyakit-penyakit mulut yang paling sering terjadi (termasuk SAR).

\section{DAFTAR PUSTAKA}

1. Field A, Longman L. Tyldesley's Oral Medicine (Fifth Edition). Oxford: Oxford University Press. 2003; p. 52-8.

2. Jurge S, Kuffer R, Scully C, Porter SR. Recurrent aphtous stomatitis. Oral Dis [serial online]. 2006 [cited 2012 May 23]; 12(1): 1-21. Available from: http://www.ncbi.nlm.nih.gov/pubmed/1 6390463.

3. Volkov I, Rudoy I, Freud T, Sardal G, Naimer S, Peleg R, et al. Effectiveness of vitamin B12 in treating recurrent aphtous stomatitis: a randomized, double-blind, placebo-controlled trial. J Am Board Fam Med [serial online]. 2009 [cited 2012 Feb 09];22(1):9-16. Available from: http://www.ncbi.nlm. nih.gov/pubmed/19124628.

4. Koybasi S, Parlak AH, Serin E, Yilmaz F, Serin D. Recurrent aphtous stomatitis: investigation of possible etiologic factors. Am J Otolaryngol [serial online]. 2006 [cited 2012 May 07];27(4): 229-32. Available from: http://www.ncbi.nlm.nih.gov/pubmed/1 6798397.

5. Neville BW, Damm DD, Allen CM, Bouquot JE. Oral and Maxillofacial Pathology (Third Edition). Philadelphia: Elsevier-Saunders. 2009. p. 285-90.

6. Volkov I, Rudoy I, Abu-Rabia U, Masalha T, Masalha R. Case report: Recurrent aphtous stomatitis responds to vitamin B12 treatment. Can Fam Physician. 2005;51:844-5.

7. Fernandes R, Tuckey T, Lam P, Allidina S, Sharifi S, Nia D. The best treatment for aphtous ulcers: an evidence-based study of literature. MeSH Dent J. 2006;7:1-7.

8. Notoadmodjo S. Promosi Kesehatan Teori \& Aplikasi. Jakarta: Rineka Cipta. 2010; p. 43-64.

9. Tilliss TSI, McDowell J. Differential diagnosis: Is it herpes or aphtous?. J Contemp Dent Pract [serial online]. 2002 [cited 2012 Mar 12];3(1):1-10. Available from: http://www.ncbi.nlm. nih.gov/pubmed/12167909.

10. Field EA, Allan RB. Review article: Oral ulceration - aetiopathogenesis, clinical diagnosis and management in the Gastrointestinal Clinic. Aliment Pharmacol Ther. 2003;18:949-62.

11. Hurlbutt M, Thomsen L. Demystifying recurrent oral ulcerations. ADA CERP PennWell [serial online]. 2007 [cited 2012 May 23];4:1-9. Available from: http://www.ineedce.com/courses/1430/ PDF/DemystRecurOralUlceratns.pdf.

12. Scully C, Gorsky M, Lozada-Nur F. The 
diagnosis and management of recurrent aphtous stomatitis: a consensus approach. J Am Dent Assoc. 2003;134:200-7.

13. Boras VV, Savage NW. Recurrent aphtous ulcerative disease: presentation and management. Aust Dent Journal. 2007;52(1):10-5.

14. Silverman S, Eversole LR, Truelove EL. Essentials of Oral Medicine. London: BC Decker Inc, 2001; p.210-7.

15. Scully C, de Almeida OP, Bagan J, Dioz
PD, Taylor AM. Oral Medicine and Pathology at a Glance. West Sussex: Wiley-Blackwell, 2010; p.56-7.

16. Scully C. Aphtous Ulceration. N Engl J Med [serial online]. 2006 [cited 2012 Feb 08];355(2):165-72. Available from: http://www.nejm.org/doi/full/10.1056/ NEJMcp054630.

17. Altenburg A, Zouboulis CC. Current concepts in the treatment of recurrent aphtous stomatitis. Skin Therapy Letter. 2008;13(7):1-4. 